'Council were pleased to hear of the appointment of Sir Desmond Pond, our immediate Past President, to the office of Chief Scientist. Professor Seager and Drs Jancar and Montgomery have been elected by Council to the Executive and Finance Committee.

'The Court has elected 54 Members to the Fellowship.

'At the most recent Membership Examination 115 candidates were successful-a pass rate of 43 per cent. The Laughlin Prize for the best candidate has been awarded to Dr I. G. McKeith.

'The Court of Electors carried out its annual review of Inceptors. All those admitted in 1976 have now completed their maximum five-year period but it has been agreed that Inceptors working part-time should be allowed to continue on a pro-rata basis. The Court also wish me to remind members of previous College recommendations on the appointment of locum consultants (Bulletin, October 1979) and of the desirability of ensuring that candidates for senior registrar posts have passed the Membership Examination.

'Council considered a report of the Special Commitee which is studying the findings of the College ECT Research Project. Council supported the suggestion that a travelling Lecturer should be appointed, who would visit College Divisions and meet a representative from each hospital or unit where ECT is given. This representative would be responsible for the general oversight of the administration of ECT and would indicate the College's views on the correct procedure for the administration of treatment. The College would also produce information leaflets and an instruction chart suitable for display in treatment suites. Discussions are taking place with representatives of the Royal College of General Practitioners, the Faculty of Anaesthetists, and the nursing organizations on the contribution of their members to the giving of ECT. It was agreed that it would be important to arrange some form of follow-up to the research in about two years' time, to investigate whether the desired improvements have taken place.

'The Public Policy Committee's Working Party which is attempting to influence the progress of the Mental Health (Amendment) Bill through the House of Lords, and soon the House of Commons. Professor Bluglass, the Convener, together with the President and other members of the working party have had several meetings with members of the House of Lords. A number of amendments have been supported or resisted in keeping with College views.

'The Cambridge Conference on Recruitment to Psychiatry will be held from 26 to 28 March.

'The College has been informed that the Central Committee for Hospital Medical Services is to set up a Psychiatric Sub-Committee, and the President, the Dean, and myself have been nominated to represent the College.

"A Conference on "Helping the Sick Doctor" is to be held in the College on 8 March. Invitations have been issued to representatives of other organizations and to certain Members of the College who have been involved in the care of sick colleagues.

'Major redecoration at the College House has now been completed in all the public rooms, with the exception of the ground floor, previously occupied by the ECT Research Team. In the course of the next few months it is intended to create a Members' Room in this area, together with an additional lecture or committee room.

'Our landlords, the Grosvenor Estate, insist that the outside of the property is painted every three years. This will be done in 1982-a costly exercise.

'The Child and Adolescent Psychiatry Section has prepared a document on the Management of Parasuicide in Young People under Sixteen. This has been approved by Council but its publication is being delayed until the Public Policy Committee's Working Party on the Management of Parasuicide in all age groups has reported.

'The College is extremely grateful to Professor Hirsch and his colleagues at Charing Cross Hospital for the arrangements made for this Quarterly Meeting. The next Quarterly Meeting will be in Liverpool on 21 April 1982.'

\title{
North-East Division: Annual Conference
}

The Sixth Annual Conference of the North-East Division was held in York on 11 September 1981. The subject of this meeting was 'The Psychiatry of the Family'. Colleagues from the nursing and social work professions were invited as well as members of the College. Predictably, the day was extremely popular and although 300 people were accommodated it was over-subscribed.

The morning was taken up with three academic contributions, one from each of the three age groups: childhood, adult life and old age. Dr Sula Wolff started the day with a masterly and succinct review of the important relationship between psychiatric disorders in childhood and family life. Mrs Elizabeth Kuipers told us about the important work on the effect of family relationships on the course of schizophrenia. Finally, Dr Garry Blessed gave a fascinating clinical account of the importance of family support in psychiatric disorder in old age, in particular senile dementia.

The afternoon session consisted of a video presentation and account of the McMaster model of family functioning and conjoint family assessment by Drs Nicol and Goodyer. This was followed by a lively discussion of the place of conjoint family work in psychiatry, the status of a 'cognitive' as against an 'experimental' focus in family work and many other issues, led by contributions from Professor Mindham and Dr Mary Ward.

A. R. Nicol 